15. Neufeld, E. F., and Cantz, M. J.: Corrective factors for inborn errors of mucopolysaccharide metabolism. Ann. N. Y. Acad. Sci., 179: 580 (1971).

16. Nordén, N. E., Lundbald, A., Ökerman, P., and Jolly, R. D.: Mannosidosis in Angus cattle: Partial characterisation of two mannose containing oligosaccharides. Fed. Eur. Biochem. Soc. Lett., 35: 209 (1973).

17. O'Brien, J. S., Miller, A. L., Loverde, A. W., and Veath, M. L.: Sanfillipo disease type B: Enzyme replacement and metabolic correction in cultured fibroblasts. Science, 181: 753 (1973).

18. Philippart, M.: Fabry disease: Kidney transplantation as an enzyme replacement technique. In: D. Bergsma: Enzyme Therapy in Genetic Diseases Original Article Series, Vol. IX (National Foundation-March of Dimes, New York, 1973).

19. Phillips, N. C., Robinson, D., Winchester, B. G., and Jolly, R. D.: Mannosidosis in Angus cattle-The enzymic defect. Biochem. J., 137: 363 (1974).
20. Thompson, K. G., Jolly, R. D., and Rammell, C. G.: Lymphocyte $\alpha$ mannosidase-A supplementary test for determining mannosidosis genotype. N. Zealand Vet. J. (1976).

21. Whittem, J. H., and Walker, D.: Neuronopathy and pseudolipidosis of Aberdeen Angus calves. J. Path. Bacteriol. 74: 281 (1957).

22. Lymphoprep, Nygegaard \& Co., Oslo, Norway.

23. B. D. H. Chemicals, Ltd., Poole, England.

24. Fluka Durcupan, ACM, Switzerland

25. This investigation was supported by National Institutes of Health Research Grant No. RO1-NS 11238-02 from the Institute of Neurological Diseases and Stroke.

26. Requests for reprints should be addressed to: R. D. Jolly, Ph.D., Faculty of Veterinary Science, Massey University, Palmerston North, New Zealand.

27. Accepted for publication November 19, 1975.
Fetus liver

human growth hormone ornithine decarboxylase insulin

\title{
Ornithine Decarboxylase Activity in Human Fetal Liver
}

DANIEL R. WOLPAW AND ALAN L. SCHWARTZ ${ }^{(24)}$

Department of Pharmacology, School of Medicine, Case Western Reserve University, Cleveland, Ohio, USA

Extract

In human fetal liver ornithine decarboxylase (EC. 4.1.1.17 $(O D C)$ ) was found to have $a K_{m}$ of $3.3 \times 10^{-4}$ M. During human fetal development, hepatic ODC activity declined from a peak of 379 $\mathrm{pmol} / 60 \mathrm{~min} / \mathrm{mg}$ protein in the youngest tissue examined $(5.2 \mathrm{~cm}$ crown-rump length, 10 weeks of gestation) to values of $1.3 \pm 0.2$ in fetuses greater than $12 \mathrm{~cm}$ (14-15 weeks of gestation). Explants of human fetal liver maintained in organ culture for $32 \mathrm{hr}$ demonstrated no ODC activity in the presence or absence of insulin (1 $\mathrm{U} / \mathrm{ml}$ ). Explants of rat fetal liver achieved a steady state of ODC activity (12\% of the fresh tissue activity) after $16 \mathrm{hr}$ in organ culture and maintained this for an additional $14 \mathrm{hr}$.

\section{Speculation}

Regulation of hepatic ODC activity in the developing human fetus may result from hormonal influences, particularly human growth hormone (HGH) and very possibly human chorionic somatomamotropin (HCS).

Ornithine decarboxylase has recently emerged as a key enzyme in the synthesis and regulation of the polyamines, spermine and spermidine (9). This enzyme is responsible for shunting ornithine from the urea cycle to produce putrescine, a necessary intermediate in polyamine biosynthesis. Putrescine combines with a compound derived from L-methionine to form spermidine, which in turn yields spermine. ODC has been characterized in a variety of tissues, including fetal rat and fetal chick (16), and to a limited extent in human fetal brain and liver (17).

Attention has focused on ODC because of the increasingly important role assigned to polyamines in nucleic acid and protein synthesis, especially in association with rapidly proliferating tissues (e.g., fetal, neoplastic, regenerating, etc.) (9). Furthermore, this enzyme is extremely sensitive to hormonal stimulation. Growth hormone produces a marked increase in activity $(1,16)$, and Mallette and Exton (5) have reported stimulation of ODC activity in perfused rat liver by both insulin and glucagon. Considering the important metabolic regulatory roles of insulin and glucagon in human fetal liver (13-15), we initiated this study to expand the data available on ODC in human fetal liver and to explore its relationship to these hormones.

This study involved characterization of ODC in developing human fetal liver.

\section{MATERIALS}

$\left[{ }^{14} \mathrm{C}\right]$ Carboxylornithine (specific radioactivity $61 \mathrm{mCi} / \mathrm{mmol}$ ) was obtained from Amersham-Searle, Des Plaines, Ill. The organ culture medium was a modified Eagle's minimal essential medium in Hank's balanced salt solution and was obtained from Grand Island Biologicals, N.Y. (12). All other chemicals were purchased from Sigma Chemical Co., St. Louis, Mo.

Human fetal liver tissue was obtained at legal therapeutic abortion by hysterotomy (19). These tissues were either quickfrozen immediately in liquid nitrogen and stored up to 1 year at $-70^{\circ}$ until assayed or were incubated in organ culture and then quick-frozen and stored at $-70^{\circ}$. Gestational ages were determined from the nomogram of Tanimura et al. (18).

All rats used were Holtzman strain Sprague-Dawley. Regenerating liver tissue was obtained $10-14 \mathrm{hr}$ after partial hepatectomy and assayed immediately or quick-frozen and stored as above. Fetal liver tissue for organ culture and developmental data were obtained from rats mated for $16 \mathrm{hr}$. The dam was killed by a blow to the head and the entire uterus was removed rapidly. The tissue 
was excised under sterile conditions and the fetal livers were either used immediately for organ culture or quick-frozen in liquid nitrogen and stored up to I year at $-70^{\circ}$ for later determination.

\section{METHODS}

The technique of organ culture employed here has been described previously $(7,12)$. Briefly, explants less than $1 \mathrm{~mm}^{3}$ were placed at the media-gas $\left(\mathrm{O}_{2}-\mathrm{CO}_{2}, 95: 5\right)$ interface for up to $32 \mathrm{hr}$ in culture. Human fetal liver tissue was preincubated for 20-24 hr before additions were made. At the appropriate time in culture, the explants were removed and quick-frozen over liquid nitrogen.

Tissues were assayed for ODC activity by a modification of the method of Russel and Snyder in which the release of ${ }^{14} \mathrm{CO}_{2}$ from orithine labeled in the $\mathrm{C}-1$ carboxy group was followed (10). After homogenization in 5 volumes of $0.05 \mathrm{M} \mathrm{KH}_{2} \mathrm{PO}_{4}$ buffer, $\mathrm{pH} \mathrm{7.2,}$ and centrifugation at $20,000 \times g$ for $20 \mathrm{~min}$ at $4^{\circ}$, an aliquot of the supernatant was assayed for ODC activity in a reaction mixture consisting of $0.05 \mathrm{mM}$ pyridoxyl-5-phosphate, $0.05 \mathrm{M} \mathrm{KH}_{2} \mathrm{PO}_{4}$ buffer, pH 7.2, DL-[1-14 C]ornithine $(61 \mathrm{mCi} / \mathrm{mmol}$ with the counts per min adjusted for the activity of the tissue: radioactive L-ornithine usually greater than $150,000 \mathrm{cpm} /$ sample), $0.25 \mathrm{mM}$ dithiothreitol, with a final volume of $0.1-2.0 \mathrm{ml}$. Blanks were prepared by using supernatant which had been heated at $80^{\circ}$ for 2 min (17). For substrate curves nonradioactive ornithine was added in varying concentrations without altering the final volume. All additions were at $4^{\circ}$ and all samples were prepared in duplicate. Each tube was then fitted with a rubber stopper supporting a polyethylene center well which contained $0.25 \mathrm{ml} \mathrm{CO}_{2}$-free $20 \%$ $\mathrm{KOH}$ as a $\mathrm{CO}_{2}$ trap. The reaction tubes were incubated at $37^{\circ}$ for up to $60 \mathrm{~min}$, at which time the reaction was terminated by the

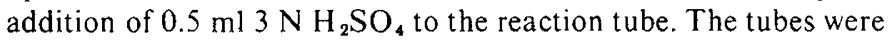
subsequently agitated for an additional $15 \mathrm{~min}$ at $37^{\circ}$. The center wells were withdrawn and placed in a glass scintillation vial containing $1 \mathrm{ml}$ glass-distilled water and $10 \mathrm{ml}$ scintillation fluid (17). The vials were counted in a Packard Tri-Carb scintillation counter after cooling.

This assay for ODC activity was linear with respect to time up to $60 \mathrm{~min}$ and with the amount of tissue (enzyme) added. Each assay determination included a series of quality control standards of known ODC activity derived from regenerating rat liver. ODC activity is expressed as pmol $\mathrm{CO}_{2}$ released from $\left[1-{ }^{14} \mathrm{C}\right]$ ornithine $/ 60 \mathrm{~min} / \mathrm{mg}$ protein.

Proteins were analyzed on the tissue supernatants according to the method of Lowry et al. (4) using bovine serum albumin as a standard.

\section{RESULTS}

As seen in Figure 1, ODC activity in human fetal liver displays an apparent $\mathrm{K}_{\mathrm{m}}$ of $3.3 \times 10^{-4} \mathrm{M}$. This value correlates well with reported values from other tissues and other species $(6,8,17)$.

The relationship of ODC activity to fetal growth is demonstrated in Figure 2. The ODC activity was greatest (379 pmol/60 $\mathrm{min} / \mathrm{mg}$ protein) in the youngest tissue examined $(5.2 \mathrm{~cm}$ crownrump length, 10 weeks of gestation) and decreased to barely detectable levels beyond $12 \mathrm{~cm}$ crown-rump length (14-15 weeks of gestation). Tissues from fetuses greater than $12 \mathrm{~cm}$ all demonstrated ODC activities in the range of $1.3 \pm 0.2(9) \mathrm{pmol} / 60$ $\mathrm{min} / \mathrm{mg}$ protein.

The development of ODC activity in the fetal rat liver obtained in this study correlates well with the data presented by Snyder et al. (16). There was a sharp peak of activity at approximately 17.5 days of gestation ( -4.5$)$, declining rapidly to approximately $7 \%$ of this level by 19.5 days of gestation.

Explants of human fetal liver $(9 \mathrm{~cm}$ crown-rump length) maintained in organ culture for $32 \mathrm{hr}$ demonstrated no detectable ODC activity (data not shown). Furthermore, the presence of insulin $(1 \mathrm{U} / \mathrm{ml})$ did not significantly increase ODC activity. In fetal (18.5 days of gestation) rat liver explants (pooled and randomized from 15 animals), ODC activity declined during the

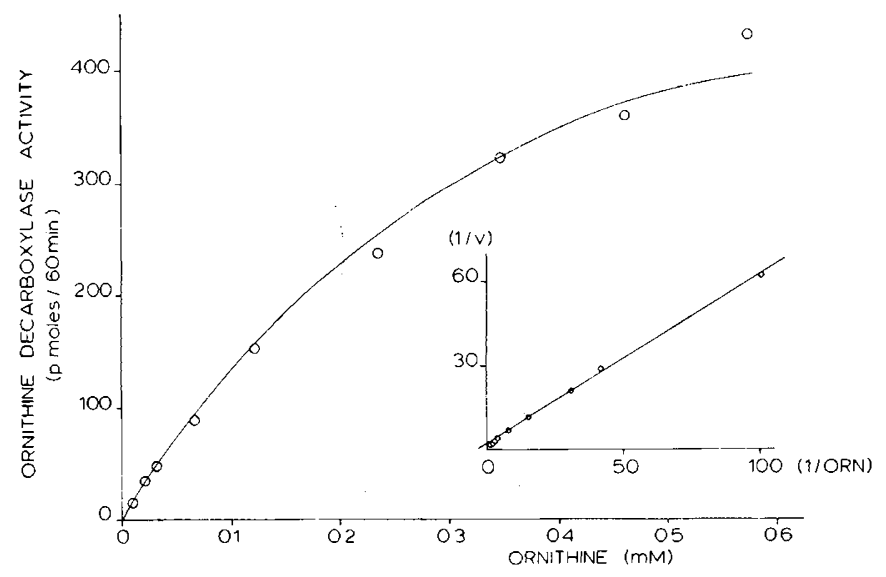

Fig. 1. Activity of ornithine decarboxylase in human fetal liver as a function of ornithine concentration. Inset: double reciprocal plot of 1 /ornithine concentration $(O R N)$ vs. 1/enzyme velocity. $\mathrm{K}_{\mathrm{m}}: 3.3 \times 10^{-4}$ $\mathrm{M}$; crown-rump length $=20 \mathrm{~cm}$.

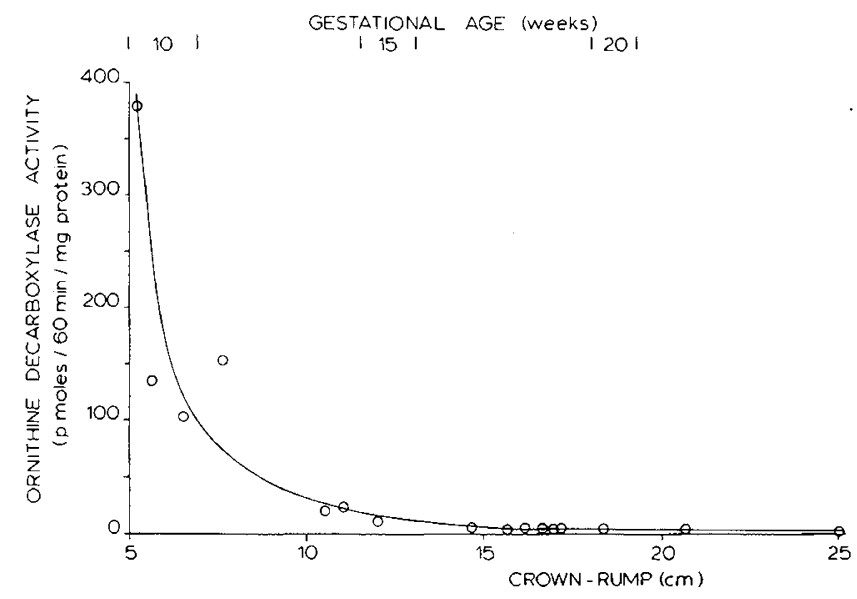

Fig. 2. Changes in ornithine decarboxylase activity during development of the human fetal liver. Each point represents the mean of duplicate samples from the same embryo. Gestational ages are adapted from the data of Tanimura et al. (18). Ornithine decarboxylase activity in samples greater than $12 \mathrm{~cm}$ crown-rump length: $1.3 \pm 0.2(9)$ (mean $t$ SEM)

first $8 \mathrm{hr}$ in culture, reaching a steady state by $16 \mathrm{hr}$, after which no further decrease in activity was observed through $30 \mathrm{hr}$. This plateau represented approximately $12 \%$ of the fresh tissue activity (20).

\section{DISCUSSION}

ODC activity in human fetal liver displays normal enzyme kinetics with respect to substrate concentration and is consistent with data from other tissues and species $(6,8,17)$. During early human fetal development ODC activity rapidly declines as seen in Figure 2. Recently it has been recognized that studies of enzymatic development from subhuman species cannot be directly compared to man (e.g., Reference 15). Sturman and Gaull (17) examined tissue from human fetuses $9-25 \mathrm{~cm}$ crown-rump length and found no significant correlation between gestational age and ODC activity. The present study confirms their observation beyond 12 $\mathrm{cm}$. Below $10 \mathrm{~cm}$, however, there is a dramatic increase in ODC activity, reaching a maximum in the youngest tissue examined.

As mentioned previously, $\mathrm{HGH}$ has been identified as a potent stimulator of ODC activity $(1,16)$. During human fetal development, HGH does not cross the placenta (3), so that serum concentrations in the fetus are entirely dependent on the developing fetal pituitary. The hormone is detectable in fetal serum concomitant with the appearance of the pituitary $(8-10$ weeks of 
gestation), rises to significantly higher values by midgestation, and then declines significantly by 30 weeks to term (2). It is possible that the peak in fetal liver ODC activity seen before 10 weeks of gestation is the result of initial exposure to $\mathrm{HGH}$ which is making its appearance at the same time, and that the subsequent decline in ODC activity despite rising serum HGH levels is the result of decreasing sensitivity to the hormone.

Another possible explanation for the developmental behavior of ODC activity lies in the presence of HCS. HCS, produced by the placenta, shares many properties with HGH (11). Human fetal serum concentrations of HCS also appear higher in the range of 11-18 weeks of gestation than later on (2). Unfortunately, the effect of HCS on ODC activity has not been studied.

Hormonal correlates of ODC activity might be profitably examined in the context of an organ culture system. Initial data on human fetal explants in organ culture is discouraging, but steady state determinations in the fetal rat liver promise an extended period of stable activity during which controlled studies of hormonal interactions might be made.

\section{SUMMARY}

The $\mathrm{K}_{\mathrm{m}}$ of ODC in human fetal liver is comparable with values obtained in other tissues and species $\left(3.3 \times 10^{-4} \mathrm{M}\right)$. The ODC activity in human fetal liver varies with the gestational age of the fetus, declining rapidly from a peak in the youngest tissue examined. Human fetal liver explants maintained in organ culture for $32 \mathrm{hr}$ demonstrate no ODC activity in the presence or absence of insulin. Rat fetal liver explants display a prolonged period of stable ODC activity after $16 \mathrm{hr}$ in organ culture.

\section{REFERENCES AND NOTES}

1. Janne, J., Raina, A., and Siimes. M.: Mechanism of stimulation of polyamine synthesis by growth hormone in rat liver. Biochim. Biophys. Acta, I66: 419 (1968).

2. Kaplan, S. L., Grumbach, M. M., and Shephard, T.: The ontogenesis of human fetal hormones. I. HGH and insulin. J. Clin. Invest., 51: 3080 (1972).

3. King, K., Adam, P. A. J., Schwartz, R., and Teramo, K.: Human placental transfer of human growth hormone- ${ }^{125}$. Pediatrics, $48: 534$ (1971).

4. Lowry, O. H., Rosebrough, N. J., Farr, A. L., and Randall, R. J.: Protein measurement with the Folin phenol reagent. J. Biol. Chem., 193: 265 (195I).
5. Mallette, L. E., and Exton, J. H.: Stimulation by insulin and glucagon of ornithine decarboxylase activity in perfused rat livers. Endocrinology, 93: 640 (1973).

6. Pegg, A., and Williams-Ashman, H.: Biosynthesis of putrescine in the prostrate gland of the rat. Biochem. J., 108: 533 (1968).

7. Räihä, N C . R Schwartz, A. L., and Lindroos, C. M. Induction of tyrosine- $\alpha$-ketoglutarate transaminase in fetal rat and fetal human liver in organ culture. Pediat. Res., 5: 70 (1971).

8. Raina, A., and Janne, J.: Biosynthesis of putrescine: Characterization of ornithine decarboxylase from regenerating rat liver. Acta Chem. Scand., 22: 2375 (1968).

9. Raina, A., and Janne, J.: Physiology of the natural polyamines: Putrescine, spermidine and spermine. Med. Biol., 53: 121 (1975).

10. Russel, D., and Snyder, S.: Amine synthesis in rapidly growing tissues: Ornithine decarboxylase activity in regenerating rat liver, chick embryo and various tumors. Proc. Nat. Acad. Sci. U.S.A., 60: 1420 (1968)

11. Saxena, B.: Protein-polypeptide hormones of the human placenta. Hormone Vit., 29: 95 (1971).

12. Schwartz, A. L.: Influence of glucagon, $\mathrm{N}^{6,2^{\prime}} \mathrm{O}$-dibutyryl adenosine cyclic monophosphate and triamcinolone on the arginine synthetase system in perinatal rat liver. Biochem. J., I26: 89 (1972).

13. Schwartz, A. L.: Hormonal regulation of amino acid accumulation in human fetal liver explants: Effect of dibutyryl cyclic AMP, glucagon and insulin. Biochim. Biophys. Acta, 362: 276 (1974).

14. Schwartz, A. L.: Hormonal regulation of glucose production in human fetal liver (Ph.D. dissertation, Case Western Reserve University, 1974).

15. Schwartz, A. L., Räihä, N. C. R., and Rall, T. W.: Effect of dibutyryl cyclic AMP on glucose-6-phosphatase in human fetal liver explants. Biochim. Biophys. Acta, 334: 500 (1974)

16. Snyder, S., Russel, D., Kreuz, D., and Medina, V.: Polyamine synthesis and turnover in rapidly growing tissues. Ann. N. Y. Acad. Sci. 171: 691 (1970).

17. Sturman, J. A., and Gaull, G.: Polyamine biosynthesis in human fetal liver and brain. Pediat. Res., 8: 231 (1974).

18. Tanimura, T., Nelson, T., Hollingsworth, R. R., and Shephard, T. H.: Weight standards for organs from early human fetuses. Anat. Rec., 17I: 227 (1971).

19. Neither author participated in the decision to interrupt pregnancy. Informed consent was obtained.

20. The activity of fetal rat liver ODC at 18.5 days of gestation is approximately 15 $\mathrm{pmol} / 60 \mathrm{~min} / \mathrm{mg}$ protein.

21. We thank Dr. J. A. Sturman for advice with the ODC assay.

22. This study was supported in part by the Cleveland Diabetes Fund and United States Public Health Service Grant no. GM-00661-11/-12.

23. Insulin (monocomponent) was a gift from Dr. J. Schlichtkrull, Novo Industri, Copenhagen, Denmark.

24. Requests for reprints should be addressed to: Alan L. Schwartz, Ph.D., Department of Pharmacology, School of Medicine, Case Western Reserve University, Cleveland, Ohio 44106 (USA).

25. Accepted for publication November 17, 1975. 